\title{
THE TRADITIONALLY UNDERSTOOD KARATE-DO AS AN EDUCATIONAL SYSTEM: APPLICATION OF THE MARTIAL ARTS’ PEDAGOGY
}

\section{Introduction}

The scientific problem undertaken here is to clarify the application of the "karate pathway" in a specific educational system. A variety of the Budo Pedagogy is applied under the name of karate-do. Is karate really an educational system?

The issue will be implemented from the perspective of the Humanistic Theory of Martial Arts and the anthropology of martial arts. ${ }^{1}$ It is the anthropology of the "warriors pathway," as we can translate Budo sensu largo. Of course, Budo sensu stricto is an untranslatable concept, as a specific fragment of Japanese culture. ${ }^{2}$

Accordingly, we accept this conceptual language of the Humanistic Theory of Martial Arts and anthropology of martial arts. For instance, "Martial arts is a historic category of flawless methods of unarmed combat fights, and the use of weapons combined with a spiritual element (personal development, also in the transcendent sphere)." 3 The ways of martial arts include certain forms of physical (psychophysical) culture, which, based on the tradition of warrior cultures, lead, through the training of fighting techniques, to a psychophysical improvement and self-realization. At the same time, they are the processes of education and positive ascetics. The positive asceticism combines corporal exercise with conscious selfdiscipline and is oriented towards moral and spiritual progress.

1 W.J. Cynarski, Teoria i praktyka dalekowschodnich sztuk, walki w perspektywie europejskiej, Rzeszów 2004; W.J. Cynarski, Antropologia sz̨uk walki. Studia i sžkice z socjologii i filozofii sz̨tuk walki, Rzeszów 2012; D. Bolelli, On the Warrior's Path. Philosophy, Fighting, and Martial Arts Mythology, $2^{\text {nd }}$ ed., Berkeley 2008.

2 Cf. Sasaki Taketo, Budo (the martial arts) as Japanese culture: the outlook on the techniques and the outlook. on the human being [in:] Martial Arts and Combat Sports - Humanistic Outlook, ed. W.J. Cynarski, Rzeszów 2009; Nakiri Fuminori, Concept of Budo and the bistory and activities of the Japanese Academy of Budo, "Ido Movement for Culture. Journal of Martial Arts Anthropology" 2015, vol. 15, no. 1, pp. 11-25.

3 W.J. Cynarski, J. Skowron, An analysis of the conceptual language used for the general theory of martial arts - Japanese, Polish and English terminology, "Ido Movement for Culture. Journal of Martial Arts Anthropology" 2014, vol. 14, no. 3, p. 63. 
Combat sport is understood as a "derivative of the martial arts traditions of the East or the West, whose distinctive feature is sports rivalry. The fight may be direct (but the rules protect the health of players) or in the form of expression of motion (demonstrational forms). Sometimes there are different formulas for competitive sports (as in kick-boxing) or competitions (as in taekwondo ITF)." 4

The methodological base is co-created here by the method of a long-term participant observation (from 1977), and the content analysis of literature, and a relatively wide discourse. ${ }^{5}$ It is therefore a particular method of practical, psychophysical study. Participant observation may be the most valuable, ${ }^{6}$ as one's own experience and the experience of others are used. Karate, as a way to overcome their own weaknesses, requires this particular individual, psychophysical experience.

In the following passages the author attempts to clarify the nature of Budo Pedagogy, the specificity of psycho-physical education systems, educational values occurring in the way of karate, the issue of authenticity of this way, and application options.

\section{The essence of Budo Pedagogy}

Educational meaning of martial arts was probably born in the Shaolin monastery (Honan Province, China). We can agree with Meir Shahar, that fighting techniques with bare hands known today were no longer at the time $\left(16^{\text {th }}\right.$ century) intended exclusively for combat, but "were meant to be used to treat and to spiritual improvement. They developed them through the fusion of gymnastics and breathing techniques - intended primarily for health and religious destiny - a martial art without weapons. This resulted in the synthesis of martial arts therapy and religious self-improvement." ${ }^{\prime \prime}$ So it was less about the effectiveness in combat, and more about the form and practice of psychophysical and the kind of educational process.

Daily practice, self-discipline, physical exertion, intellectual and emotional, are here for personality and omni improvement. Persistent training is connected with the improvement of character. The process can only be effective and have a noticeable impact on the personality of the people practicing the variety of Budo if it is extended in time. That is the right way to a lifelong self-improvement in humanity and a mastery of technical skills (forms) and self-defence (free fight) are not the only goal here.

4 Ibidem, p. 61.

K. Krippendorf, Content Analysis: An Introduction to Its Methodology, Thousand Oaks 2004.

6 Cf. W.J. Cynarski, Teoria i prakttyka..., pp. 22-26; D.C. Spencer, Ultimate fighting and embodiment. Violence, gender, and Mixed Martial Arts, New York 2012, pp. 166-168.

7 M. Shahar, Klasætor Shaolin. Historia, religia i chinskkie sұtuki walki, trans. by J. Hunia, Kraków 2011, p. 235. 
The pedagogy of martial ways is not a separate pedagogical sub-discipline, however, draws much from the Holistic Pedagogy. ${ }^{8}$ This fits especially to the new paradigm of humanities and pedagogy - a recommendation for a comprehensive recognition of human research and human reality. The psychophysical human being and the educational process recognized systematically, humanely and in numerous dimensions of socio-cultural conditions (contextual dimension) are at the centre of attention. It is also a process (temporal dimension), including teaching, training and education (axiological dimension). ${ }^{9}$

This applies to all various methods, sports or ways of $B u d o$, as aikido, judo, kendo, iaido, so also karate-do. Grand Master (GM) Gichin Funakoshi has introduced karate to the pantheon of Japanese Budo. Similarly, some other masters of Okinawan martial arts originally started to associate karate with the modern ethos of Bushido. ${ }^{10}$ Japanese karate-do today is ideologically close to other varieties of Budo. And all the characters/varieties of Budo combine the idea articulated in the Budo Charter.

The Budo Charter was drafted in the hope that the principles of traditional Budo submitted here will be maintained. In the next six articles it was highlighted that:

1) Aim - the purpose of Budo continues to cultivate character, expand the capacity assessment and settlement, in the physical and spiritual education with the participation of fighting techniques.

2) Keiko (exercise) - in today's exercise you have to constantly follow the rules of modesty, to remain faithful to the foundations and not yield to temptations to cultivate training focused on technical skills at the expense of striving for the unity of spirit and technique.

3) Shiai (competition) - in combat sports and kata performing the spirit of Budo must be manifested. Effort to the end! You win with modesty, receive a willing to lose and present the right attitude anyway!

4) Dojo - it is a sacred place for the formation of our body and soul. Discipline, proper etiquette and ceremonial must be applied. The exercising area must offer a quiet, clean, safe and serious atmosphere.

8 Budo - Pädagogik. Kampf-Kunst in Erziehung, Therapie und Coaching, eds. J.-M. Wolters, A. Fußmann Albert, Augsburg 2008; J. Słopecki, W.J. Cynarski, O pedagogice budo, "Ido - Ruch dla Kultury / Movement for Culture" 2009, vol. 9, pp. 258-260; cf. A. Szyszko-Bohusz, The problem of the proper ethical and social preparation of teachers and participants of combat sports and martial arts in the contemporary epoch of globalisation, science and technology, "Ido - Ruch dla Kultury / Movement for Culture” 2007, vol. 7, pp. 38-40; W.J. Cynarski, W. Błażejewski, W. Pasterniak, Pedagogika nowoparadygmatyczna. W poszukiwaniu nowych inspiracji i aplikacji pedagogicznych, Rzeszów 2016, pp. 123-162.

9 W.J. Cynarski, W. Błażejewski, W. Pasterniak, Pedagogika nowoparadygmatycænna...

$10 \mathrm{~J}$. Piwowarski, Moral strength and safety culture. Revitalizing the West in view of Japanese conceptions, "Ido Movement for Culture. Journal of Martial Arts Anthropology" 2013, vol. 13, no. 4, pp. 7-15. 
5) Teaching - to be an effective teacher, the master of Budo must constantly strive to cultivate the character and abilities of their students and encourage the process of mastering the spirit and the body. He (she) should not be lost by victory or become shaky or show arrogance, but maintain an exemplary attitude.

6) Popularisation - in the dissemination of Budo, one should follow traditional values and essence of the training, as a last resort, bring the concept of the traditional arts and explore and keep their understanding in the international reception. ${ }^{11}$

$$
* * *
$$

The pedagogy of martial arts is an application of their philosophy or theory. We can find at least a few concepts of Budo pedagogy or martial arts pedagogy, for example the canon of holistic pedagogy used in education through martial arts. The questions of spirituality and consciousness are perceived differently by the Polish pedagogue, many-sided humanist and mystic, practitioner of Yoga and karate, Andrzej Szyszko-Bohusz. He connected the ethos of Far-Eastern martial arts with the Holistic Pedagogy that he created. The holistic didactic-educational process aims at a many-sided development and spiritual renewal of man. The sensei should be the pattern of values, through his personal example. ${ }^{12}$

Sometimes normative ethics and the discipline of martial arts are used for the education or re-socialisation of young people in Europe. ${ }^{13}$ Results of numerous psychological studies indicate that training of many varieties of martial arts reduces aggressiveness in athletes (there are, however, some controversies in this area). For example, some German researchers from the group of Matthias von Saldern, practicing karate and judo. They created the ideal (pedagogical model) of the warrior of peaceful mind, calm, agreeable and peaceful, as the German term - der friedliche Krieger may be translated. ${ }^{14}$ Perhaps it is partly an idealisation of Far-Eastern myths and legends, maybe an attempt to contemporarily apply the old ethos in the pure, model form, but a successful attempt, positively verified in the pedagogical experience.

11 W.J. Cynarski, Karta Budo. Analiza treści ₹.perspektyny bumanistyçnej teorii sz̨tuk walki, „Polish Journal of the Arts and Culture" 2013, no. 7(4), pp. 31-53.

12 Cf. A. Szyszko-Bohusz, Pedagogika holistyczna [in:] Przemiany w myśli i praktyce pedagogicznej, eds. M. Feiner, A. Szyszko-Bohusz, Kraków 1998, pp. 151-165; W.J. Cynarski, K. Obodyński, H. Zeng, Martial arts anthropology for sport pedagogy and physical education, "Romanian Journal for Multidimensional Education Lumen" 2012, vol. 4, no. 2, pp. 133-156.

13 E.g. Budo-Pädagogik. Kampf-Kunst in Erziehung...

14 Der friedliche Krieger. Budo als Methode der Gewaltprävention, eds. U. Neumann, M. von Saldern, R. Pöhler, P.-U. Wendt, Marburg 2004. 
Dr Jigoro Kano was one of the first to write about the contribution of judo in education. Many other educators try to emulate Kano in the application of judo and other martial arts/martial ways. Budo and mushin, terms from samurai Bushido code and combat Zen, are used in educational concepts. However, the system of Budo values is much more universal. The values can be adopted in every system of normative ethics. ${ }^{15}$

Knight's bushiculture emerged not only as samurai ethos, but also survived in the tradition of martial arts in the form of canons of noble conduct, attitudes - toward the teacher and hierarchy, symbolism and heritage of generations of masters. Empirical studies confirm that the ethos of Bushido and knightly virtues (butoku) are still alive in the environment of people practicing karate. ${ }^{16}$

Sensei (teacher) is a master and a model - an authority because of their skills and knowledge, but above all, a personality. In the history of martial arts the teacher chose a worthy student. Currently, in the era of the realities of the market economy and widespread commercialization, more and more students choose the master. As an attractive person and an authority, they have to respect him. This has a significant impact on the effectiveness and on the attitudes of students, their moral internalisation and other conditions. It is a different relationship than between a coach and a player. Especially, the master (a holder of a minimum of 8 dan degrees and a hanshi title) is usually much older than their students. As a result, he (or she) is able to give them more insight into life, not just into fighting.

The master is an author of, and at the same time, a work of martial arts. The student imitates him, repeating the movements of his fighting techniques. He (she) copies even his art. He (she) is susceptible to the personal influence of a teacher who is an expert here, and with whom the student is identified. The teacher must be aware of the responsibility for the moral education of their students.

\section{Budo and other educational systems}

Despite the fact that the discipline of martial arts does not include do (the pathway) in its name, it may well be the educational system, with established normative ethics - rules of conduct not only in the dojo, but in life. An example can be

15 D. Bolelli, On the Warrior's Path...; R.L. Light, Mushin and learning in and beyond budo, "Ido Movement for Culture. Journal of Martial Arts Anthropology" 2014, vol. 14, no. 3, pp. 42-48.

${ }_{16}$ C. Kuśnierz, Values associated with practicing modern karate as a form of cultivating old Japanese Bushido patterns, "Ido Movement For Culture. Journal of Martial Arts Anthropology" 2011, vol. 11, no. 4, pp. 1-5; V.A.V. Rosa, "Samurais" in modern Europe: motivations and understandings of Portuguese karatekas, "Ido Movement for Culture. Journal of Martial Arts Anthropology" 2012, vol. 12, no. 2, pp. 11-19. 
numerous organizations of jujutsu, though of course not all. ${ }^{17}$ Also the preferred name, whether it is karate, or karate-do, does not determine how certain values are emphasized.

Karate is practiced for different purposes, and you can specify different ways of doing it: sports competition, gaining self-defence skills, professional use (the uniformed services, instructors), self-development and improvement. ${ }^{18}$ The same applies to other martial arts.

Classical, Japanese schools of martial arts (ko-ryu) taught complete systems of wielding weapons and any fighting techniques. An example is found in a $15^{\text {th }}$-century school Tenshinshoden Katorishinto-ryu, cultivated till today. ${ }^{19}$ It was necessary then to train as a complete warrior. But then they also cared about his moral formation. Later varieties (judo, aikido, karate, in general: Gendai Budo) teach the most common single methods of combat, and usually without the use of weapons.

Educational systems of martial arts were established also outside of Japan. In the warrior cultures of India, China, Korea, Thailand and other countries, local varieties of martial arts have been cultivated till today, where in addition to teaching the techniques and tactics they brought up a good man. Christian knights of Europe have developed a special ethos of nobility. For example, Polish schools of wielding a sabre, where the ethos values are strongly stressed, as GM Wojciech Zabłocki School ${ }^{20}$ and the Signum Polonicum ${ }^{21}$ are practiced in Poland till today.

Taekwondo, created and developed on the basis of karate, is a separate educational system, and even two separate (versions: International Taekwon-Do Federation, ITF, and the World Taekwondo Federation, WTF). The symbolism refers today to the culture of Korea, it teaches other technical forms, it also has a separate set of rules of conduct. Or are these separate branches of the tree of martial art tradition? Various martial arts are an inspiration for each other, and this applies to both fighting techniques, as well as the canons of ethics and axiology. ${ }^{22}$

Educational process in sport (in training and teaching) or in the physical education can also be a source of improvement of personality. The condition is here, however,

17 J. Słopecki, Ocena programón edukacyjnych jüjutsu w Polsce (PhD thesis), Warszawa 2010.

18 J. Skórska, The roads of modern karate [in:] Humanistic Theory of Martial Arts and Combat Sports: Conceptions and Problems, eds. W.J. Cynarski, K. Obodyński, Rzeszow 2003, pp. 129-135

19 Sugino Yoshio, Ito Kikue, Tenshin Shoden Katori Shinto Ryu Budo Kyohan, trans. by U. Rott, Norderstedt 2010; of. Tanaka Fumon, Samurai fighting arts: the spirit and the practice, Kodansha International 2003.

20 W. Zabłocki, Polskie sұtuki walki. Miecz oburečny i szabla busarska, Podkowa Leśna 2001.

21 Z. Sawicki, Polish Martial Art - Signum Polonicum, "Ido Movement for Culture. Journal of Martial Arts Anthropology" 2011, vol. 11, no. 2, pp. 38-46.

22 Cf. U. Moenig, Taekwondo - From a martial art to a martial sport, London 2015; H.Z. Zeng, W.J. Cynarski, Participation Motivations of Taekwondo Athletes / Students, Saarbrücken 2016. 
adherence to the noble principles of fair play. ${ }^{23}$ Education through sport can be successfully implemented in clubs of fencing, boxing, wrestling and in other combat sports. However, tough competition for the results brings the risk of pathology.

\section{Educational values of karate/karate-do}

Karate, in its different varieties of style, multilaterally develops physically (level of motor skills, physical fitness, hardening). It is also rich in tools of educational influence. They belong to the same: the authority of the teacher, hierarchical system, discipline in the dojo and standards for behaviour outside the dojo, the traditional way of teaching. ${ }^{24}$ These non-sports are a component of motivation for practicing karate. ${ }^{25}$

The same is just the exercise of basics (kihon), technical forms (kata), free fighting (kumite), tests of breaking (shiwari) and moments of silence to control the breath influence on the improvement of people exercising self-control. Weapons and equipment used in karate, as sai, sticks and other (in general - bukinobu), improve motor skills, especially coordination, strengthen arms, teach martial art in different distances. It is also a legacy of centuries of tradition. In addition, in Okinawan Goju-ryu karate we find special exercises, for example force, developing oriented efficiency.

The fight, especially when it is required to stop the blows, teaches self-control and responsibility. It is also an important test of skills and psycho-physical preparation. It allows to know the nature of the enemy and to improve self-knowledge. Many of today's karateka want especially to fight. Numerous karate organizations entered the path of competitive sports training young people were eager to participate in. ${ }^{26}$ Fighting in combat sports can be regarded as a test of skills and psychophysical preparation. The aim of this test (especially for the nature of the warrior) is to participate in a summer camp and overcome their own weaknesses.

Although GM Funakoshi unequivocally rejected sport competition, his successors introduced karate to the varieties of sports. For as long as Gichin Funakoshi and Shigeru Egami were alive, sport competitions were not organized in their schools, as they were regarded by them as contrary to the spirit of karatedo. Classic karate, the authentically traditional (not the activity which has usurped its name) does not

\footnotetext{
23 K. Warchol, W.J. Cynarski, Olympism and fair play in physical education in the light of Polish theoretical reflection, "Journal of Health Promotion and Recreation" 2012, no. 2(4), pp. 33-37.

24 The History and Spirit of Budō, eds. T. Uezumi, A. Bennett, Katsuura 2010.

25 Cf. C. Kuśnierz, Values associated Rosa...; H.Z. Zeng, W.J. Cynarski, Participation Motivations...

26 R. Jakhel, W. Pieter, Changes in primary motives of karate beginners between 1970-1999, "Ido Movement for Culture. Journal of Martial Arts Anthropology" 2013, vol. 13, no. 1, pp. 48-57.
} 
need sports rivalry. The original Okinawan karate, Isshin-ryu or Doshinkan, rejects sport competition. The same applies to the Zendo karate style Tai-te-tao (Idokan karate) which originated in Germany. Here, sports rivalry is rejected as harmful for the personal development of people practicing it. However, the sport competitions are in fact in many karate organisations nowadays.

The traditional form of knowledge transferred are the technical forms, so-called kata. They contain the technical essence of the style. "Kata are a predetermined series of blocks, evading and countering techniques against single or multiple attackers, who may be armed or unarmed. (...) in the Ryukyu islands the tradition of secrecy was passed on by direct instruction from master to student, very often on a one-to-one basis, and the historical background to the kata was transmitted by oral tradition, a notoriously imprecise method." ${ }^{28}$ However, it is not only the technical basis. "Kata in karate is a unique, specific to the culture of the Far East, and original system for the transfer of knowledge and skills. (...) Kata, in the literal sense, is a formula, model or shape and so all activities are performed exactly according to a predetermined plan. The number of movements, positions, directions and ways of movement, rhythm and pace and breathing in kata are very specific. They all have a purpose, and the ignorance of their importance distorts them greatly. (...) As with a poem or piece of music, we should understand it in its own way based on its internal structure. In its unique character lies the identity of each style." ${ }^{29}$

It is worth to practice these forms, along with their interpretation called bunkai. The bunkai is praced particularly in karate Goju-ryu, ${ }^{30}$ but not only. It is practicing for self-defence, too; for fighting skills against a group of aggressors. This dimension of kata is mentioned by a part of experts (as Morio Higaonna, 10 dan karate Goju-ryu, hanshi; Steve Arneil, 9 dan karate Kyokushin, hanshi). ${ }^{31}$

Self-defence skills are a very important motivation for karate practitioners. According to GM Lothar Sieber (10 dan karate-do, hanshi), karate was originally mostly martial arts (arts of self-defence) and real fighting. GM Matson (1963) uses the term karate-jutsu. Only regular exercising in self-defence, as in the style of Zendo karate Tai-te-tao, provides real skills for this style there is a separate group

27 C. Layton, M. Higaonna, S. Arneil, Karate for self-defence: An analysis of Goju-ryu and Kyokushinkai kata, "Perceptual and Motor Skills" 1993, no. 77(3), pp. 829-830; J. Bachmeier, F. Uebrück, Zendo Karate Tai-Te-Tao Kata, Regensburg 1999; M. Rosenbaum, Kata and transmission of knowledge in traditional martial arts, Boston 2005; P. Szeligowski, Tradycyjne karate Kyokushin. Budo i walka sportowa, Lódź 2009.

28 V. Morris, A. Trimble, Karate Kata and Application, vol. 3, London 1991, p. 7.

29 P. Szeligowski, Tradycyjne karate Kyokushin..., p. 92.

30 C. Layton, M. Higaonna, S. Arneil, Karate for self-defence...; G. Hahnemann, Goju-Ryu KarateDo. Kata and Bunkai, Thalheim 2003; H. Kogel, Kata Bunkai. Die geheimen Techniken im Karate, Aachen 2010.

31 Cf. C. Layton, M. Higaonna, S. Arneil, Karate for self-defence... 
of self-defence techniques on the curriculum. ${ }^{32}$ In addition, one should practise responses to real attacks, rather than to classical or conventional ones. In meijin Sieber's school competitive sport is discarded and the training programme is aimed at fighting in a real situation. ${ }^{33}$ GM Roland Habersetzer (9 dan karate, hanshi) expressed in this similar sentence. ${ }^{34}$

As opposition to adding a sporty character of karate Peter Jahnke created Zendo Karate Tai-Te-Tao style of the Way of Hand of Peace. ${ }^{35}$ There is no sporting event. The essence of sport and sport goals are not identical with the way of Budo, so many Grand Masters reject this rivalry. Others accept it, but in different formulas/conventions.

Either way, karate contains the values not found in other sports. And this applies to different schools, provided an appropriate level of competence of instructors. Among the many utilitarian values, health and educational may be mentioned. Among the educational values karate-do accepted the values present in the Budo.

Generally it can be said that Budo (as axionormative system) introduces a certain ethos of universal values: the protection of life, honour, respect for cultural traditions, also for authority, fidelity to the principles of the way of moral conduct. ${ }^{36}$

The warrior pathway cultivated today rejected the cruel and dark side of the old Bushido, with a warrant for revenge and honour suicide. Today Budo is a humanised and humanitarian adaptation of martial way, interpreted etymologically, as a way of non-aggression. Their moral part and educational function are emphasized. The way of the twenty-first century warrior, as a path of noble aspirations for the truth and higher values, is not conditioned by any religious tradition - it may well be associated with the practice of the Christian or Zen Buddhism. It is universal as a message of striving for a broader perfection and a moral challenge. And as such it is accepted by people of different cultures and social strata. ${ }^{37}$

The universal sense of duty, care for the honour and dignity, of personal integrity and confidence in the word, is transmitted to the way of Budo, understood more as a way and art of life, than of martial arts only. The principles of nobility and daily

32 L. Sieber, Zendo Karate Tai-Te-Tao [in:] Selected Areas of Intercultural Dialogue in Martial Arts, ed. W.J. Cynarski, Rzeszów 2011, pp. 145-154.

33 W.J. Cynarski, The meaning of self-defence: an expert definition. A contribution to the theory of selfdefence and combat [in:] Proceedings of $10^{\text {th }}$ International Conference on Kinanthropology: "Sport and Quality of Life", eds. M. Zvonař, Z. Sajdlová, Brno 2016, pp. 463-474.

${ }^{34}$ Cf. R. Habersetzer, Tengu (-no-michi). Ma voie martiale: Pour un art martial aux normes de notre temps, Paris 2007.

35 J. Bachmeier, F. Uebrück, Zendo Karate...

36 A. Litwiniuk, W.J. Cynarski, Educational and utylitarian value of practising combat sports and martial arts [in:] Humanistic Theory of Martial Arts..., pp. 123-128.

37 W. Ben Messaoud, Social representations of karate among young people, "Ido Movement for Culture. Journal of Martial Arts Anthropology” 2015, vol. 15, no. 4, pp. 39-48. 
work on ourselves are opposing the modern fashion of easy, light, and pleasant life, and the desire for a career at all costs.

With a sense of personal power and efficiency due to a sense of security. It improves the sense of his/hers own self-control and emotional relationships. While he karateka cesses ethical normative values, it becomes a better person. What is the heart of karate? "Its true essence is to train the body, mind and spirit together in order to realize the fullness of human potential." ${ }^{\text {38 }}$

\section{Authenticity and traditionalism of karate}

Original karate was born in Okinawa and its historical heritage of the Ryu Kyu kingdom. To this day, classic styles are cultivated there, as, inter alia Uechi-ryu and Shorin-ryu. A modernized version are the main styles of Japanese karate (Shotokan, Goju-ryu, Shito-ryu, Wado-ryu, Kyokushin) and derivatives thereof. Another schools then were formed outside Japan.

Some authors distinguish between traditional karate and sport karate, others style of demonstration (sho karate), traditional (karate-do) and combat-oriented self-defence (karate-jutsu). ${ }^{39}$ In return, GM Hidetaka Nishiyama and his school use the name "traditional karate" to highlight the observance of rules of conduct in combat and in life. ${ }^{40}$

Alexander Staniszew (Shirin-ryu karate 8 dan, kyoshi) sees intrinsic value in the tradition of Okinawa. In his opinion recent trends are clearly moving in the direction of "a healthy and fun way to spend your time." ${ }^{41}$ He believes that: "There is only one original, the Okinawan. Japanese karate is far different from the original an incomplete copy. If you mix tea with beer, it is not going to be either tea or beer. The same will be the case with Okinawan karate and its Japanese copy." ${ }^{42}$

The authenticity of karate is decided basing especially on three factors: 1) fidelity to the idea launched by the monks of Shaolin; 2) practical skills; 3) the lineage of a particular school or organisation. It is important which disciple is whose, as the transfer of skills is accompanied by transfer of a set of values.

\footnotetext{
38 S. Mor-Stabilini, The Essence of Karate-do: Sankido Example, "Ido Movement for Culture. Journal of Martial Arts Anthropology" 2013, vol. 13, no. 4, pp. 45-48.

39 G.E. Mattson, The Way of Karate, Tokyo 1963.

40 Cf. Hidetaka Nishiyama, R.C. Brown, Karate. The Art of "Empty-Hand" Fighting, BostonVermont-Tokyo 1990

41 A. Staniszew, qtd. in: W.J. Cynarski, Karate in Europe - Institutional development and changes: "karatedo wa rei ni hajimari, rei ni owaru koto wo wasuruna", "Research Journal of Budo" 2014, vol. 46, no. 3, pp. $168-183$.

42 Ibidem.
} 
The dispute about the originality, authenticity or genuineness makes sense only for the typology of karate varieties. The issue settlement depends on the criteria. In the light of the three criteria adopted above, an authentic karate school must be: 1) in accordance with its original axiology (protect life, self-defence and avoidance of violence - the famous words by Funakoshi: Karatedo wa ni hajimari rei, rei than owaru koto wo wasuruna); 2) pursue teaching at a good technical level; 3) teach in the transmission from master to student.

In total, it is especially important, who is considered as the main champion of the organization. Karate, understood in a traditional way, is teaching values, also goes beyond sports and physical culture. It is then the recommendable educational system.

\section{Applications}

According to the typology by Bolelli there are five varieties of fighting arts that can be analysed: 1) performance arts; 2) internal arts; 3) weapons arts; 4) self-defence arts; 5) combat sports (grappling, striking, and combined). ${ }^{43}$ In karate we find some motivations for practicing it: the first (kata for show), the second (as meditative movement forms), the $3^{\text {rd }}$ (karate weapons - in many schools), the $4^{\text {th }}$ (by accent in teaching for self-defence), the $5^{\text {th }}$ (karate tournaments), also almost all possibilities.

The institutionalising of karate includes the creation of organisations, new schools, and regulations (e.g. concerning sports, arbitration and fighting), the adoption of teaching methods and methods of promotion through the ranks, the granting of licences to instructors and referees, promotion to higher sports classes, etc. This leads to the establishment of new schools, which are mostly inauthentic or eclectic. Many experts point out that sports rivalry is contrary to the spirit of karatedo. Some emphasise the teaching of real self-defence skills, whereas others stress the educational meaning of practice. We can generally distinguish: 1) a pedagogical or humanistic approach when karate-do is the way of improving personality; 2) treating karate as entertainment; 3) focusing on the utilitarian values of karate and fighting, as an expression of the worship of power or for the need of safety. ${ }^{44}$

In practice, they are functioning based on the teaching karate programmes by R. Habersetzer, W.J. Cynarski, M. von Saldern, C. Spring, and others. ${ }^{45}$ Szeligowski

43 D. Bolelli, On the Warrior's Path..., pp. 115-140.

${ }_{44}$ Gichin Funakoshi, Karate-do - My Way of Life, Tokyo-New York-San Francisco 1975; P.K. Jahnke, Zen-Do Karate "Tai-Te-Tao", München 1992; W.J. Cynarski, Karate in Europe..., pp. 168-183.

45 R. Habersetzer, Tengu (-no-michi)...; W.J. Cynarski, Teoria i praktyka...; W.J. Cynarski, Martial Arts - Idō \& Idōkan, Rzeszów 2009; M. von Saldern, Bushido. Etbik des japanischen Ritters, $2^{\text {nd }}$ ed., Lüneburg 2009; Meisterung des Ichs. Budō zur Gewaltprävention?, hrsg. M. von Saldern, Nordstedt 2011; C. Spring, Martial Arts: Application in Higher Education, Ex-L-Ence Publishing [b.m.] 2015; 
creates his programme on the basis of the existing concept of Kyokushin karate. ${ }^{46}$ Some teachers create new directions, schools and methods.

Meijin Sieber has been developing an idea of GM Peter Jahnke - Zendo karate Tai-Te-Tao, and by GM Wally Strauss - Idokan karate. ${ }^{47}$ Here the struggle is a positive co-operation, humanistic ideals are carried there and the struggle is not to demonstrate superiority over martial brothers. In turn, the technique is not limited by any convention of sportsmanship. A rich repertoire of techniques is taught - basic and special. In free fighting, however, every karateka must show a full self-control. The accent falls on the humanistic sense of self-realisation and self-creation, and instead of rivalry a widely understood perfectionism is preferred.

There are educational systems based on teaching and education through practical studies of one school and method, like Kyokushin karate (in some versions), or for some Budo disciplines. For example, Habersetzer created Tengu-ryu for karatedo, kobudo (6 weapons) and hojutsu (shooting). It is the idea of returning to the origins of martial arts, that we should train for the real skills in self-defence. ${ }^{48}$ Just like it looks in the Idokan system (karate, jujutsu, kobudo, etc.). ${ }^{49}$ Parallel studies karate and fighting in contact (e.g. jujutsu) and the fight with/against weapons (kobudo) give a fuller preparation for customised combat situation.

The promises to introduce karate curricula (and other martial arts) in higher education are interesting. It is, for example, academic education at the undergraduate level in the field of martial arts' pedagogy, performed on one of the British universities. Charles Spring (6 dan karate, renshi) made an interesting experiment, teaching students and looking for the pedagogical results..$^{50}$

There are also awarded degrees in the field of sport sciences in various other countries (behind United Kingdom) and has been running a group of fully qualified experts. ${ }^{51}$ Only well-educated staff can ensure proper development for the public good. It would be a sort of a repetition of the way of karate from Japan to the West - by Japanese academic clubs. ${ }^{52}$

Masutatsu Oyama, The Kyokushin Way. Mas. Oyama's Karate Philosophy, Tokyo 1979; Der friedliche Krieger...; Budo-Pädagogik...; L. Sieber, Zendo Karate...; S. Mor-Stabilini, The Essence of Karate-do...

46 P. Szeligowski, Tradycyjne karate Kyokushin...; of. Masutatsu Oyama, The Kyokushin Way...

47 Cf. P.K. Jahnke, Zen-Do Karate...; J. Bachmeier, F. Uebrück, Zendo Karate ...; L. Sieber, W.J. Cynarski, $A$ new stage in the history of the Idokan organization, "Ido Movement for Culture. Journal of Martial Arts Anthropology” 2013, vol. 13, no. 3, pp. 59-71.

48 R. Habersetzer, Tengu (-no-michi)..., pp. 17-333.

49 W.J. Cynarski, Martial Arts - Idōo,.., pp. 9-269.

50 Cf. Ch. Spring, Martial Arts...

51 L. Sieber, P. Pawelec, Professors of martial arts. Holders of this title in martial arts science, "Ido Movement for Culture. Journal of Martial Arts Anthropology" 2016, vol. 16, no. 3, pp. 15-26.

52 M. Ashkenazi, Ritual and the ideal of society in karate [in:] Combat, Ritual, and Performance. Anthropology of the Martial Arts, ed. D.E. Jones, Westport, Connecticut-London 2002, pp. 99-118; The History and Spirit of Budō..., pp. 16-24, 101-118. 
Meanwhile, we do not know whether the Budo values will win in the competition with market economy principles. Extreme commercialization means that in many karate organisations almost everything is for sale. Minors receive master's degrees. Lower grades are awarded often regardless of their skill. It also happens that the self-styled masters teach and award degrees without having the right competence. Instructors and entire organizations compete in that business.

Another pathology is the politicisation of martial arts. ${ }^{53}$ This applies to the entanglement of martial arts (including karate) in political sports policy of the state, use or restrict the development. Politicians representing the national authorities are awarded honorary degrees, including the highest. It is associated with the extreme commercialization, partly a consequence of this particular pathology.

In general, these pathologies are a small margin, and the activities of most organisations and individuals-enthusiasts work very well for the development of physical culture and the formation of pro-social attitudes of youth. So karate is used even in rehabilitation/re-socialisation. ${ }^{54}$

\section{Summary - the results of own observation}

Karate is changing, because the cultural background and motivation of the people practising it is changing. Two major trends dominate the development of karate: the preservation of orthodox teaching and that of continuous modifications. In particular the representatives of the strictly Japanese schools and organisations, opt to keep the spirit of Budo alive through karate.

Because karate is a part of Budo, we are dealing here with the case of the educational system, in which the values of Budo are used for the proper development of the student. This involves a long-term teaching and raising him by a normative system and daily discipline of physical exercise, or rather psychophysical.

Karate, in its various forms, brings numerous educational values. However, a teacher chooses a student basing on their personality. Only a good teacher is able to properly use karate to positively influence the character and personality of a student. The master's own example is especially important. And it is usually a long process. Karate, traditionally understood, teaches traditional values, and is recommendable as the educational system.

53 Cf. W.J. Cynarski, Droga sætuk walki a polityka, "e-Politikon. Kwartalnik Naukowy Ośrodka Analiz Politologicznych Uniwersytetu Warszawskiego” 2015, no. 13, pp. 195-220.

54 Budo - Pädagogik...; J. Lee-Barron, Martial arts training as a method of modifying attitudes and behaviours in the classroom, "Ido Movement for Culture. Journal of Martial Arts Anthropology" 2012, vol. 12, no. 1, pp. 25-29. 
In general, the activities of most organisations and individuals-enthusiasts serve very well for the development of physical culture and the formation of pro-social attitudes of the young. So karate is used even in social rehabilitation. However, in the case of schools focused on competitive sports or extremely commercialized, pedagogical application would be potentially harmful.

\section{STRESZCZENIE}

\section{TRADYCYJNIE ROZUMIANE KARATE JAKO SYSTEM EDUKACYJNY - ZASTOSOWANIE PEDAGOGIKI SZTUK WALKI}

Karate się zmienia, ponieważ zmienia się tło kulturowe i motywacja osób, które je uprawiaja. W rozwoju karate dominują dwa główne nurty: zachowanie ortodoksyjnej nauki oraz ciagłej modyfikacji. W szczególności przedstawiciele tradycjonalistycznych japońskich szkół i organizacji podtrzymują ducha Budo poprzez praktykowanie karate.

Ponieważ karate jest częścią Budo, mamy do czynienia z systemem edukacyjnym, w którym wartości Budo są wykorzystywane do prawidłowego rozwoju ucznia. Wiąże się to z długoterminową nauką $i$ wychowaniem przez system normatywny i codzienną dyscyplinę fizyczna, a raczej psychofizyczna.

Karate, w różnych jego formach, przynosi liczne wartości edukacyjne. Jednak nauczyciel wybiera ucznia na podstawie jego osobowości. Tylko dobry nauczyciel jest w stanie właściwie wykorzystać karate, aby pozytywnie wpłynąć na charakter i osobowość ucznia. Przykład dawany przez samego mistrza jest szczególnie ważny. Zwykle jest to długi proces. Karate, tradycyjnie rozumiane, uczy tradycyjnych wartości i jest godne polecenia jako system edukacyjny.

Zasadniczo działania większości organizacji i entuzjastów bardzo dobrze służą rozwojowi kultury fizycznej i kształtowaniu prospołecznych postaw młodzieży. Karate jest wykorzystywane również w resocjalizacji. Jednak w przypadku szkół nastawionych na sporty wyczynowe lub całkowicie skomercjalizowanych zastosowanie pedagogiczne mogłoby okazać się szkodliwe. 